\title{
Mobilnost stanovništva u Hrvatskoj iz perspektive životnoga ciklusa
}

DOI: $10.11567 /$ met.32.1.1 UDK: 314.72(497.5)"2010/2011" Izvorni znanstveni rad Primljeno: 30. 03. 2016. Prihvaćeno: 18. 04. 2016.

\author{
Ivan Čipin
}

Ekonomski fakultet, Sveučilište u Zagrebu, Zagreb

icipin@efzg.hr

\section{Marin Strmota}

Ekonomski fakultet, Sveučilište u Zagrebu, Zagreb mstrmota@efzg.hr

\section{Petra Međimurec}

Ekonomski fakultet, Sveučilište u Zagrebu, Zagreb pmedimurec@efzg.hr

\section{SAŽETAK}

Rad istražuje unutarnju mobilnost stanovništva u Hrvatskoj iz perspektive životnoga ciklusa. U nedostatku kohortnih podataka o unutarnjoj migraciji primjenom metoda tablice doživljenja omogućena je procjena cjeloživotne prostorne pokretljivosti stanovništva. Ishod je očekivana migracija, odnosno prosječni očekivani broj preseljenja za pojedinca tijekom njegova životnog vijeka (uz uvažavanje djelovanja mortaliteta). Za izračun očekivane migracije upotrijebljeni su popisni podaci o stanovništvu koje je promijenilo mjesto stanovanja od 1. travnja 2010. do 31. ožujka 2011. Rezultati provedene analize pokazuju sljedeće: žene u Hrvatskoj prostorno su pokretljivije od muškaraca, a to vrijedi i kad se u obzir uzmu spolne razlike u mortalitetu; očekivana migracija s dobi postupno pada, no distribucija preseljenja neujednačena je tijekom životnoga ciklusa. Najveća sklonost unutarnjoj mobilnosti bilježi se, nimalo iznenađujuće, kod mladoga odraslog stanovništva, što potvrđuju i procjene modelskoga dobnog profila unutarnjih migranata u Hrvatskoj. Vrhunac intenziteta unutarnje migracije javlja se tijekom dvadesetih godina života. Istovremeno, unutarnja mobilnost stanovništva u Hrvatskoj komparativno je jako niska, što se, između ostaloga, može pripisati načinu rješavanja stambenoga pitanja, ekonomskim i društvenim prilikama. Pri interpretaciji istraživačkih nalaza izloženih u ovome radu valja imati na umu da se očekivana migracija temelji na presječnim podacima i iskustvu sintetičke kohorte. Riječ je o pokazatelju koji se odnosi na prosječne vrijednosti, zbog čega može prikrivati važne informacije o varijacijama u migracijskome ponašanju. Bez obzira na spomenuto ograničenje očekivana migracija predstavlja lako razumljivu i praktičnu mjeru koja omogućuje detaljno sagledavanje vremenskoga rasporeda prostorne pokretljivosti i tako nadopunjuje postojeće spoznaje o unutarnjoj mobilnosti stanovništva u Hrvatskoj.

KLJUČNE RIJEČI: migracija, unutarnja mobilnost stanovništva, perspektiva životnoga ciklusa, Hrvatska 


\section{UVOD}

Prostorna mobilnost stanovništva očituje se u obliku unutarnje ili vanjske migracije. Ta je tematika u Hrvatskoj iz motrišta različitih znanstvenih polja relativno dobro istražena (Gelo, Akrap i Čipin, 2005; Klempić Bogadi i Lajić, 2014; Lajić, 2002; Mikačić, 2000; Nejašmić, 1992, 2015; Pokos, 1999). ${ }^{1}$ Podaci o migracijskim zalihama dostupni su iz popisa stanovništva (Popis stanovništva, kućanstava i stanova 2011. godine), a detaljnije informacije o migracijskim tokovima službena državna statistika redovito objavljuje na godišnjoj razini (Migracija stanovništva Republike Hrvatske).

Vanjska migracija zauzima važno mjesto $\mathrm{u}$ istraživanjima o prostornoj pokretljivosti u Hrvatskoj (Nejašmić, 2015; Lajić, 2002; Pokos, 1999; Gelo, Akrap i Čipin, 2005) jer u usporedbi s fertilitetom i mortalitetom pokazuje sve izraženiji učinak na promjenu broja stanovnika, osobito u kratkome roku. Ovaj je rad usmjeren na unutarnju migraciju u Hrvatskoj, koju je također potrebno razumjeti i precizno kvantitativno odrediti jer utječe na veličinu i sastav stanovništva lokalnih jedinica. Unatoč dostupnim podacima postojeće je znanje o unutarnjoj migraciji manjkavo jer gotovo ništa nije poznato o broju selidbi koje pojedinac u Hrvatskoj tijekom života ostvari. Procjena toga broja naziva se očekivanom migracijom.

Informacije o očekivanoj mobilnosti pružaju dublji uvid u najdinamičniju (ali i teško predvidivu) sastavnicu kretanja broja stanovnika i mogu biti korisne pri izradi projekcija migracije. Nadalje, očekivana migracija kao mjera nudi nekoliko prednosti: transparentnost, intuitivnost, praktičnost i neposrednu usporedivost (što se odnosi na različite skupine stanovništva, područja i razdoblja). Dakle, rezultati izloženi u ovome radu omogućit će ocjenu intenziteta prostorne pokretljivosti stanovništva u Hrvatskoj - tijekom analizom obuhvaćenoga razdoblja i razrađenu prema dobi i spolu - $\mathrm{u}$ odnosu na ostale zemlje za koje je taj pokazatelj dostupan.

Postupak izračuna očekivane migracije zasniva se na primjeni metoda tablice doživljenja. Iako su izvorno namijenjeni izučavanju mortaliteta, alati tablice doživljenja upotrebljivi su i u drugim područjima, što je u demografskoj literaturi već prepoznato (vidi: Jaffe, 1960). No, analiza migracije tehnikama tablice doživljenja specifična je i zahtijeva uvođenje određenih pretpostavki koje će biti detaljnije objašnjene u ostatku rada. Naime, migracija (za razliku od umiranja) demografska je pojava koja se može ponavljati.

Za detaljniji pregled radova o migraciji objavljenih u ovome časopisu vidi:

Klempić Bogadi i sur. (2015: 118-141). 
Ponavljajući događaji u demografiji metodološki su zahtjevni i traže kvalitetne, ali ne uvijek i dostupne podatke.

Kako bi se unutarnja migracija što kvalitetnije istražila, potrebno je razmotriti mijenja li se i u kojoj mjeri tijekom životnoga ciklusa. Dobna obilježja unutarnjih migranata u dosadašnjim su istraživanjima temeljito ispitana i ključna su za razumijevanje mobilnosti stanovništva u razvijenim zemljama (Rogers, Racquillet i Castro, 1978; Rogers i Castro, 1981, 1986; Bates i Bracken, 1982; Rogers, 1988; Rogers i Rajbhandary, 1997; Raymer i Rogers, 2008; Wilson, 2010; Bernard, Bell i Charles-Edwards, 2014a). Ustanovljeno je da empirijski oblici intenziteta unutarnje migracije prema dobi pokazuju konzistentne pravilnosti. No, poznavanje dobnoga profila unutarnjih migranata nedovoljno je za određivanje koncentracije prostorne pokretljivosti stanovništva zemlje od interesa u određenim fazama životnoga ciklusa.

Precizne informacije o unutarnjoj migraciji tijekom životnoga ciklusa zahtijevaju podatke iz registra stanovništva ili detaljne individualne podatke o rezidencijalnim promjenama iz anketnih istraživanja. Iako su takvi podaci o unutarnjoj migraciji u Hrvatskoj nedostupni, do procjene broja selidbi koje pojedinac tijekom života ostvari može se doći primjenom alata tablice doživljenja. Wilber (1963) je prvi u istraživanju unutarnje migracije upotrijebio spomenuti pristup te na primjeru Sjedinjenih Američkih Država predstavio koncept i ilustrirao postupak određivanja očekivane migracije. Tu je metodu dodatno razvio Long (1970, 1973, 1988), a dostupni su i noviji izračuni očekivane migracije u Sjedinjenim Američkim Državama (Kulkarani i Pol, 1994; US Census Bureau, 2016). Što se ostalih zemalja tiče, očekivana migracija upotrijebljena je $\mathrm{u}$ (komparativnoj) analizi unutarnje mobilnosti $\mathrm{u}$ Australiji, Velikoj Britaniji i Japanu (Bell, 1996; Bell i sur., 2002; Long i Boertlein, 1976; Rees i sur., 2000). U tablici 1 navedene su vrijednosti očekivane migracije $^{2} u$ različitim zemljama i razdobljima iz dosad spomenutih izvora.

Budući da se u literaturi navedenoj u tablici 1 izračun očekivane migracije provodio na osnovi (anketnih ili popisnih) podataka koji nisu sadržavali informacije o rezidencijalnim promjenama novorođenčadi (vidi: Kulkarani i Pol, 1994: 197; Rees i sur., 2000: 210-211), autori su odredili odgovarajuće vrijednosti za dob 1 (i više). Neke procjene vrijednosti očekivane migracije pri rođenju postoje te su navedene u tablici 1 (odnosi se na istraživanja Bell i sur., 2000; Rees i sur., 2000). U ovome radu dostupni podaci (dobiveni putem drukčije postavljenoga pitanja iz popisa stanovništva: vidi opis raspoloživih podataka) omogućuju utvrđivanje vrijednosti očekivane migracije pri rođenju bez posebnih prilagodbi. 
Tablica 1. Očekivana migracija - tablični pregled literature

Table 1. Migration expectancy - literature review table

\begin{tabular}{|c|c|c|c|}
\hline Istraživanje & Zemlja & Razdoblje & $\begin{array}{c}\text { Očekivana } \\
\text { migracija }\end{array}$ \\
\hline Wilber (1963) & $\begin{array}{l}\text { Sjedinjene Američke } \\
\text { Države }\end{array}$ & 1958. - 1959. & 13,0 \\
\hline Long (1973) & $\begin{array}{l}\text { Sjedinjene Američke } \\
\text { Države }\end{array}$ & 1966. - 1971. & 12,9 \\
\hline \multirow{3}{*}{$\begin{array}{l}\text { Long i } \\
\text { Boertlein } \\
(1976)\end{array}$} & Japan & \multirow{3}{*}{1970.} & 7,4 \\
\hline & $\begin{array}{l}\text { Sjedinjene Američke } \\
\text { Države }\end{array}$ & & 12,9 \\
\hline & Velika Britanija & & 8,2 \\
\hline \multirow{3}{*}{$\begin{array}{l}\text { Kulkarani i } \\
\text { Pol (1994) }\end{array}$} & \multirow{3}{*}{$\begin{array}{l}\text { Sjedinjene Američke } \\
\text { Države }\end{array}$} & 1975. - 1976 & 11,2 \\
\hline & & 1980. - 1981 & 10,7 \\
\hline & & 1987. - 1991 & 11,4 \\
\hline Bell (1996) & Australija & 1985. - 1986 & 11,2 \\
\hline \multirow{8}{*}{$\begin{array}{l}\text { Bell i sur. } \\
\text { (2002), Rees i } \\
\text { sur. (2000) }\end{array}$} & \multirow{4}{*}{ Australija } & \multirow{2}{*}{ 1980. - 1981} & 10,7 (muškarci) \\
\hline & & & 11,1 (žene) \\
\hline & & \multirow{2}{*}{ 1995. - 1996.} & 12,8 (muškarci) \\
\hline & & & 13,6 (žene) \\
\hline & \multirow{4}{*}{ Velika Britanija } & \multirow{2}{*}{ 1980. - 1981.} & 6,4 (muškarci) \\
\hline & & & 6,7 (žene) \\
\hline & & \multirow{2}{*}{ 1990. - 1991.} & 6,2 (muškarci) \\
\hline & & & 6,5 (žene) \\
\hline $\begin{array}{l}\text { United States } \\
\text { Census } \\
\text { Bureau (2016) }\end{array}$ & $\begin{array}{l}\text { Sjedinjene Američke } \\
\text { Države }\end{array}$ & 2007. & 11,7 \\
\hline
\end{tabular}

U literaturi (Bell, 1996; Bell i sur., 2002) se često spominju određene prednosti koje očekivana migracija nudi kao pokazatelj unutarnje pokretljivosti stanovništva neke zemlje. Prvo, očekivana migracija statistički je validna i konceptualno jasna mjera koja je ujedno lako razumljiva i jednostavna za interpretaciju (Bell, 1996). Drugo, oslanjajući se na primjenu standardnih tehnika tablice doživljenja, očekivana migracija pruža mogućnost ispitiva- 
nja vremenskoga rasporeda unutarnje mobilnosti tijekom životnoga vijeka (Long, 1988; Bell, 1996). Treće, stacionarno stanovništvo iz tablice doživljenja koje se upotrebljava pri određivanju očekivane migracije automatski služi kao oblik standardizacije (Wilber, 1963) i uklanja učinak promjenjive strukture stanovništva prema dobi kod provedbe usporednih analiza. ${ }^{3} \mathrm{Iz}$ tih se razloga očekivana migracija često preporučuje za upotrebu u komparativnim istraživanjima (Bell, 1996; Bell i Muhidin, 2009; Bell i sur., 2002; Rees i sur., 2000). No, iako se postojeći radovi nerijetko bave međunarodnim usporedbama unutarnje pokretljivosti stanovništva i pripadajućim pokazateljima (Bell i Charles-Edwards, 2013; Bell, Charles-Edwards, Ueffing i sur., 2015; Bell i Muhidin, 2009; Bell i sur., 2002; Courgeau, Muhidin i Bell, 2012; Long, 1991; Rees i sur., 2000) i unatoč naporima koji su usmjereni na razumijevanje metoda prikupljanja (Bell, Charles-Edwards, Kupiszewska i sur., 2015; Rees i sur., 2000) i razvoj baze podataka (Bell, Charles-Edwards, Kupiszewska i sur., 2015; Bernard, Ueffing i sur., 2014; Stillwell i sur., 2014) potrebnih za izradu komparativnih istraživanja o razmatranoj temi, vrijednosti očekivane migracije dostupne su tek za mali broj zemalja (tablica 1), što je ponajviše posljedica nedostatka dovoljno detaljnih podataka (vidi: Bernard, Ueffing i sur., 2014). Dakle, ovaj će rad izračunom i analizom očekivane migracije omogućiti komparativno valjanu ocjenu prostorne pokretljivosti stanovništva u Hrvatskoj. Na taj će se način nadopuniti spoznaje o unutarnjoj migraciji u Hrvatskoj (vidi: Klempić Bogadi i Lajić, 2014; Mikačić, 2000; Nejašmić, 1992).

Intenzitet prostorne pokretljivosti stanovništva u Hrvatskoj procijenit će se iz perspektive životnoga ciklusa. Prvo će se istražiti dobni profil unutarnjih migranata kako bi se provjerilo odgovaraju li rezultati tipičnim modelskim oblicima. Zatim će se prikazati postupak izračuna očekivane migracije, koja zauzima središnje mjesto $u$ ovome radu. $U$ radu se polazi od nekoliko osnovnih hipoteza: unutarnja mobilnost stanovništva Hrvatske relativno je niska, dobni profil unutarnjih migranata u skladu je s uobičajenim modelskim oblicima i žene su ponešto mobilnije od muškaraca. Drugim riječima, traže se odgovori na sljedeća istraživačka pitanja:

1. Kako mobilnost stanovništva u Hrvatskoj varira tijekom životnoga ciklusa?

2. Koliko će se puta pojedinac u Hrvatskoj preseliti tijekom (preostaloga) životnog vijeka?

Na usporedbu očekivane migracije među zemljama i razdobljima djelovat će i potencijalne razlike u mortalitetu, što je poželjno na primjeren način uvažiti (Bell i sur., 2002; Rees i sur., 2000). 


\section{OPIS RASPOLOŽIVIH PODATAKA}

Podaci koji se upotrebljavaju u ovome istraživanju odnose se na Popis stanovništva, kućanstava i stanova 2011. godine ${ }^{4}$ i pripremljeni su na zahtjev autorâ. Preciznije, podaci su izvedeni iz popisnoga pitanja Živi li osoba neprekidno od rođenja u naselju popisa?, uz koje su se, za osobe s negativnim odgovorom, prikupljale i informacije o tome odakle se osoba doselila (iz drugoga naselja unutar Hrvatske ili inozemstva), kada se doselila (za doseljene u 2010. dostupan je i mjesec doseljenja) i zašto. Na osnovi prikupljenih informacija za potrebe ove analize sastavljena je baza (agregatnih) podataka o stanovništvu koje se doselilo u Hrvatsku od 1. travnja 2010. do 31. ožujka 2011. prema pojedinačnoj dobi i spolu, odvojeno za doseljene iz Hrvatske i inozemstva. Intenzitet unutarnje migracije izračunat je za svaku dobnu skupinu $x$ i posebno za muškarce i žene formulom

$$
m_{x}=k \frac{M_{x}}{P_{x}}
$$

gdje $m_{x}$ označuje intenzitet unutarnje migracije, $k$ konstantnu vrijednost, ${ }^{5}$ $M_{x}$ broj unutarnjih migranata, a $P_{x}$ procjenu stanovništva na početku vremenskoga intervala na koji se podaci odnose (ne sadržava doseljene iz inozemstva, kao ni stanovništvo koje se tijekom definiranoga razdoblja odselilo iz Hrvatske ili umrlo). Riječ je, dakle, o podacima koji unutarnju migraciju tretiraju kao tranziciju, ${ }^{6}$ odnosno broje se (preživjeli) unutarnji migranti, a ne preseljenja (Courgeau, 1979; Rees i sur., 2000). Način određivanja intenziteta unutarnje migracije dan izrazom (1) u skladu je s preporukama za rad s opisanom vrstom podataka (Rees i sur., 2000), a ishodišne vrijednosti predstavljaju vjerojatnosti unutarnje migracije (uvjetovane doživljenjem unutar zemlje i specifične prema dobi i spolu), koje služe kao ulaz u predstojećoj analizi.

4 Podaci za 2001. također su bili dostupni, no zbog popisnoga pitanja nisu se mogle identificirati osobe koje su se preselile u godini dana do popisnoga trenutka (podaci su pokrivali razdoblje od petnaest mjeseci do popisnoga trenutka). Nakon prilagodbe populacije izložene riziku dobiveni rezultati značajno ne odstupaju od onih za 2011., što opravdava njihovo neuključivanje u ovaj rad.

5 Riječ je o skalaru koji obično poprima vrijednost 100 (Rees i sur., 2000).

6 Još jedan često upotrebljavan tip podataka temelji se na konceptu kretanja (preseljenje u tome slučaju predstavlja događaj) i broji svaku rezidencijalnu promjenu (vidi: Bell i sur., 2002; Rees i sur., 2000). Uobičajeni su izvor takvih podataka registri stanovništva. 
Budući da raspoloživi podaci identificiraju unutarnje migrante na osnovi pitanja o posljednjoj promjeni mjesta stanovanja, zanemarena je mogućnost višestrukih preseljenja (pretpostavlja se jedna tranzicija u određenome fiksnom razdoblju, u ovome slučaju u godini dana do popisnoga trenutka). U popisima stanovništva rijetko se prikupljaju dovoljno precizne informacije o rezidencijalnim promjenama, pa broj preseljenja može biti podcijenjen. Ipak, upotreba podataka koji se odnose na jednogodišnji vremenski interval unutar kojega se mjeri broj (unutarnjih) migranata superiorna je oslanjanju na podatke o rezidencijalnim promjenama unutar petogodišnjega vremenskog intervala (Bell i sur., 2002; Kulkarani i Pol, 1994). Primjer izračuna očekivane migracije na osnovi podataka o tranzicijama unutar petogodišnjega razdoblja dostupan je u literaturi (Bailey i Sly, 1987), no dovodi do varljivih zaključaka (Bell i sur., 2002). Problem razvoja i usporedbe pokazatelja koji se izvode pomoću podataka o tranzicijama unutar različitih vremenskih intervala privukao je mnogo istraživačke pozornosti (Courgeau, 1979; Kitsul i Philipov, 1980; Long i Boertlein, 1990; Rogerson, 1990), no kraće razdoblje ostavlja manje mjesta za neidentificirana preseljenja, zbog čega se općenito preporučuje za upotrebu pri određivanju očekivane migracije (Bell, 1996; Bell i sur., 2002; Kulkarani i Pol, 1994).

\section{DOBNI PROFIL UNUTARNJIH MIGRANATA U HRVATSKOJ}

Unutarnja migracija proces je koji je selektivan prema dobi, što je demografima dobro poznato. Već je napomenuto da dobna obilježja unutarnjih migranata poprimaju dosljedne empirijske oblike. Rogers i sur. (1978) prvi su uveli matematički model putem kojega su saželi i opisali regularnosti opažane u svojstvima dobnih profila unutarnjih migranata.

\section{Specifikacija modela}

U literaturi su identificirane četiri široke skupine dobnih profila unutarnjih migranata (Rogers i Castro, 1981, 1986; Rogers i Watkins, 1987; Raymer i Rogers, 2008; Rogers, Little i Raymer, 2010). Neke od njih u stiliziranoj su formi prikazane na slikama u nastavku. Standardni dobni profil unutarnjih migranata (slika 1) podrazumijeva veću sklonost preseljenju mladoga odraslog stanovništva, što se pripisuje promjenama mjesta stanovanja koje se mogu povezati sa završetkom obrazovanja, pronalaženjem posla i procesom formiranja partnerstva. Nakon vrhunca uočljivoga kod radno sposobnoga stanovništva, slijedi postupan pad intenziteta unutarnje migracije zbog utjecaja koji nepovoljno djeluju na prostornu pokretljivost (poput sta- 
bilnoga zaposlenja, akumulacije imovine i imanja djece). Ostali dobni profili unutarnjih migranata proširuju standardnu inačicu. Prvo proširenje obuhvaća sekundarni vrhunac intenziteta unutarnje migracije, koji se odnosi na porast sklonosti preseljenju u dobi oko odlaska u mirovinu, kad pojedinci mijenjaju mjesto stanovanja kako bi pronašli rezidencijalnu lokaciju s najprimjerenijim svojstvima. Drugo proširenje uvažava sve učestalija preseljenja najstarijega kontingenta stanovništva, koja se mogu objasniti prelaskom na institucionalnu skrb. Konačno, cjeloviti dobni profil unutarnjih migranata uključuje oba spomenuta proširenja (slika 2). Intenzitet unutarnje migracije djece odraz je prostorne pokretljivosti njihovih roditelja: preseljenja su češća u mlađim dobnim skupinama (u razdoblju unutar kojega su i roditelji mobilniji), rjeđa tijekom tinejdžerskih godina, a potom iznova pokazuju uzlazno kretanje jer dolazi do napuštanja obiteljskoga doma.

Slika 1. Standardni dobni profil unutarnjih migranata

Figure 1. Standard age profile of internal migration

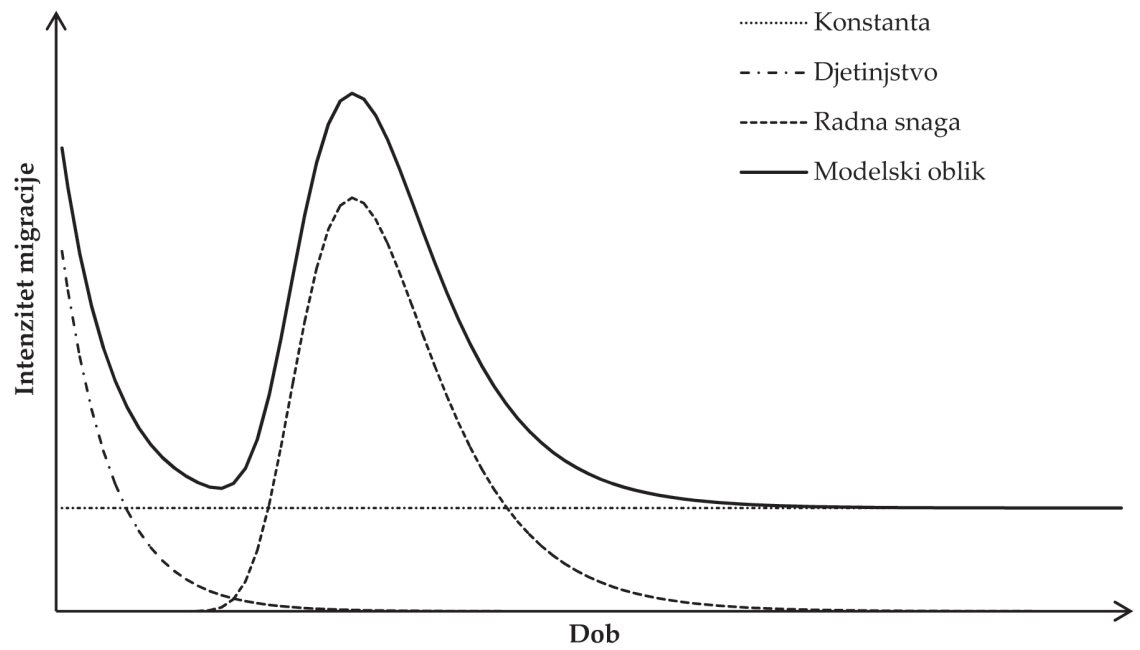

Izvor: prilagođeno za potrebe ovoga rada prema Wilson (2010) 
Slika 2. Cjeloviti dobni profil unutarnjih migranata

Figure 2. Full age profile of internal migration

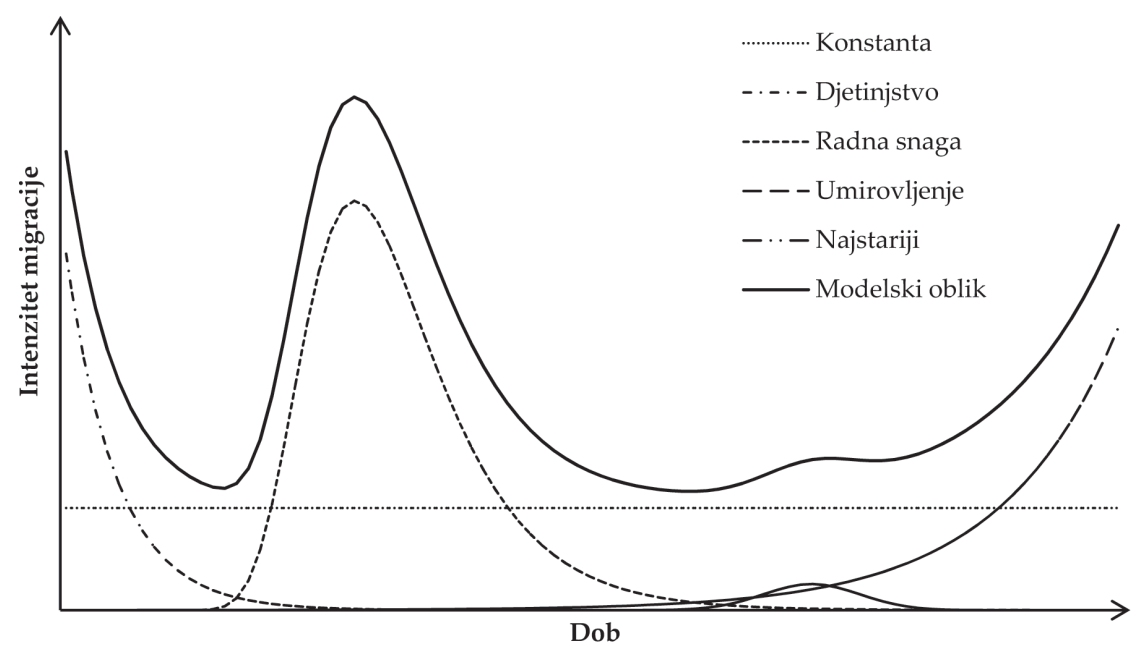

Izvor: prilagođeno za potrebe ovoga rada prema Wilson (2010)

Modelski je oblik dobnoga profila unutarnjih migranata složena eksponencijalna funkcija sastavljena od nekoliko dijelova. Ta funkcija u slučaju cjelovitoga dobnog profila unutarnjih migranata sadržava pet komponena$\operatorname{ta}^{7}$ (vidi i sliku 2). Može se definirati izrazom (Wilson, 2010)

$$
\begin{array}{ll}
m(x)= & \\
& a_{1} \exp \left(-\alpha_{1} x\right)+ \\
& a_{2} \exp \left\{-\alpha_{2}\left(x-\mu_{2}\right)-\exp \left[-\lambda_{2}\left(x-\mu_{2}\right)\right]\right\}+ \\
& a_{3} \exp \left[-\left(\frac{x-\mu_{3}}{\sigma_{3}}\right)^{2}\right]+ \\
& a_{4} \exp \left(\alpha_{4} x\right)+
\end{array}
$$

U literaturi je dostupna i nadogradnja cjelovitoga dobnog profila unutarnjih migranata koja uključuje studentska preseljenja (obično na gradska područja) u obrazovna središta (Wilson, 2010). 
gdje komponenta (a) predstavlja krivulju koja se odnosi na djetinjstvo, komponenta (b) krivulju koja se odnosi na radno sposobno stanovništvo, komponenta (c) krivulju koja se odnosi na razdoblje oko umirovljenja, ${ }^{8}$ a komponenta (d) krivulju koja se odnosi na najstarije. Pritom $m$ označuje intenzitet unutarnje migracije koji se modelira, $x$ dob, a pripadni se parametri iz izraza (2) definiraju na sljedeći način:

$a_{1}=$ visina krivulje koja se odnosi na djetinjstvo

$\alpha_{1}=$ stopa pada krivulje koja se odnosi na djetinjstvo

$a_{2}=$ visina krivulje koja se odnosi na radno sposobno stanovništvo

$\lambda_{2}=$ stopa rasta krivulje koja se odnosi na radno sposobno stanovništvo $\alpha_{2}$ = stopa pada krivulje koja se odnosi na radno sposobno stanovništvo $\mu_{2}=$ položaj krivulje koja se odnosi na radno sposobno stanovništvo na ordinati

$a_{3}=$ visina krivulje koja se odnosi na razdoblje oko umirovljenja

$\sigma_{3}=$ stope rasta i pada krivulje koja se odnosi na razdoblje oko umirovljenja

$\mu_{3}=$ položaj krivulje koja se odnosi na razdoblje oko umirovljenja na ordinati

$a_{4}=$ visina krivulje koja se odnosi na najstarije

$\alpha_{4}=$ stopa rasta krivulje koja se odnosi na najstarije

$c=$ konstanta.

Opisivanje dobnih obilježja unutarnjih migranata na određenome području gotovo će uvijek zahtijevati krivulju koja se odnosi na djetinjstvo, krivulju koja se odnosi na radno sposobno stanovništvo i konstantu (Rogers i Castro, 1981), no krivulja koja se odnosi na razdoblje oko umirovljenja i krivulja koja se odnosi na najstarije bit će potrebne samo u nekim slučajevima. U mnogim je regionalnim primjenama krivulja koja se odnosi na razdoblje oko umirovljenja najprimjetnija u iseljavanju iz gradskoga okruženja i useljavanju u toplija ili priobalna područja (Plane i Heins, 2003; Rogers i Watkins, 1987; Rogers, 1988), a rastući intenzitet unutarnje migracije kod najstarijih bilježi se kad raspoloživi podaci uključuju informacije o preseljenjima na razini naselja (Rogers i Watkins, 1987).

8 Izvorno (Rogers i Watkins, 1987) komponenta (c) u izrazu (2) ima oblik dvostruke eksponencijalne funkcije: $a_{3} \exp \left\{-\alpha_{3}\left(x-\mu_{3}\right)-\exp \left[-\lambda_{3}\right]\left(x-\mu_{3}\right)\right\}$, no Wilson (2010: 199) pretpostavlja simetričnu formu te sastavnice modela i nudi oblik cjelovitoga profila unutarnjih migranata $\mathrm{s}$ dvanaest (umjesto trinaest) parametara. 


\section{Procjene parametara}

Kako bi se odredilo koji od tipičnih modelskih oblika najbolje odgovara dobnim obilježjima unutarnjih migranata u Hrvatskoj, upotrijebljena je dostupna programska podrška (Wilson, 2010). ${ }^{9}$ Procedura procjene modela provedena je na osnovi izvedenih vjerojatnosti unutarnje migracije u Hrvatskoj ${ }^{10}$ (vidi opis raspoloživih podataka). Rezultati su navedeni u tablici 2 i prikazani na slikama 3 i 4 .

Tablica 2. Modelski dobni profil unutarnjih migranata u Hrvatskoj procjene parametara

Table 2. Model age profile of internal migration in Croatia - parameter estimates

\begin{tabular}{lccc}
\hline \multirow{2}{*}{ Komponenta } & Parametar & $\begin{array}{c}\text { Procjena } \\
\text { muškarci }\end{array}$ & Procjena žene \\
\hline \multirow{2}{*}{ Djetinjstvo } & $a_{1}$ & 0,01950 & 0,01661 \\
\cline { 2 - 4 } & $\alpha_{1}$ & 0,19046 & 0,19518 \\
\cline { 2 - 4 } Radna snaga & $a_{2}$ & 0,04361 & 0,07119 \\
\cline { 2 - 4 } & $\lambda_{2}$ & 0,14805 & 0,20163 \\
\cline { 2 - 4 } & $\alpha_{2}$ & 0,15895 & 0,19946 \\
\cline { 2 - 4 } Umirovljenje & $\mu_{2}$ & 27,91000 & 24,14510 \\
\cline { 2 - 4 } & $a_{3}$ & 0,00166 & 0,00151 \\
\hline \multirow{2}{*}{ Najstariji } & $\sigma_{3}$ & 5,39637 & 5,00023 \\
\hline Konstanta & $\mu_{3}$ & 63,29878 & 60,00533 \\
\hline
\end{tabular}

Izvor: izračun autorâ po uzoru na Wilson (2010)

$9 \quad$ Applied Demography Toolbox (2016). Tom Wilson's SPMMS: Student Peak Model Migration Schedule (Excel spreadsheet), http://www.demog.berkeley.edu/ eddieh/toolbox.html (14. 03. 2016.).

10 Procijenjena su dva modela: za muškarce i žene odvojeno. Vjerojatnosti unutarnje migracije odnose se na osobe koje su u trenutku popisa stanovništva imale od 0 do 90 i više navršenih godina života, što znači da su godinu dana prije popisa stanovništva imale od 0 do 89 i više navršenih godina života (za novorođenčad pripadni interval odgovara razdoblju od rođenja do 0 navršenih godina života); dob prikazana na slikama 3 i 4 predstavlja prosječne navršene godine života za svaku kohortu unutar promatranoga jednogodišnjeg vremenskog intervala. 
Slika 3. Dobni profil unutarnjih migranata u Hrvatskoj - muškarci

Figure 3. Age profile of internal migration in Croatia - males

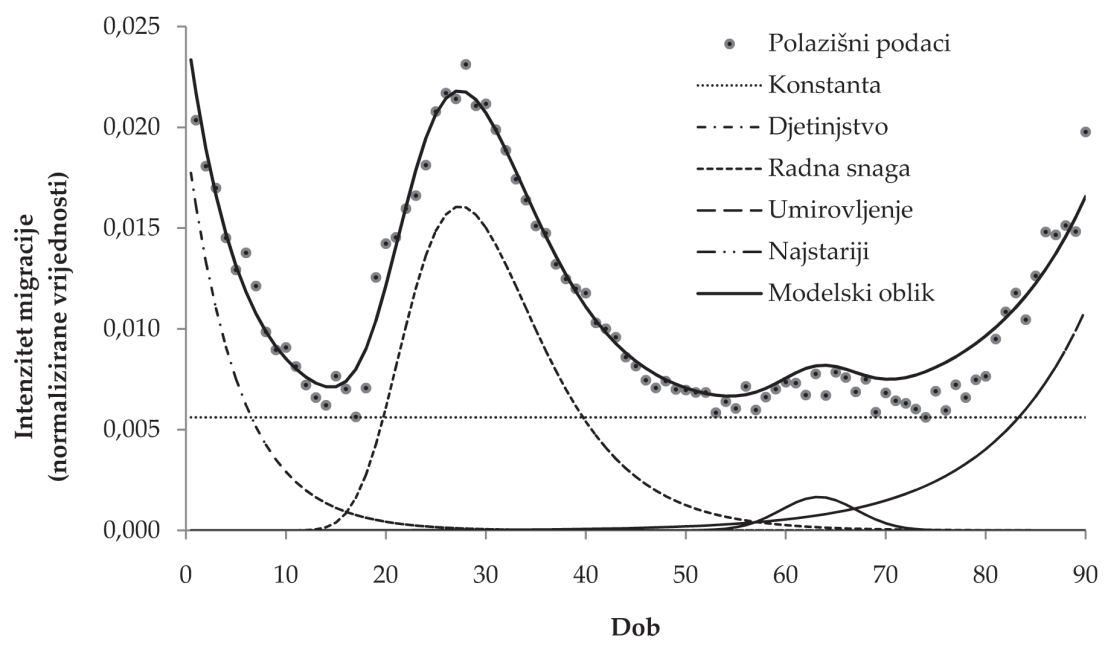

Izvor: izračun autorâ po uzoru na Wilson (2010)

Slika 4. Dobni profil unutarnjih migranata u Hrvatskoj - žene Figure 4. Age profile of internal migration in Croatia - females

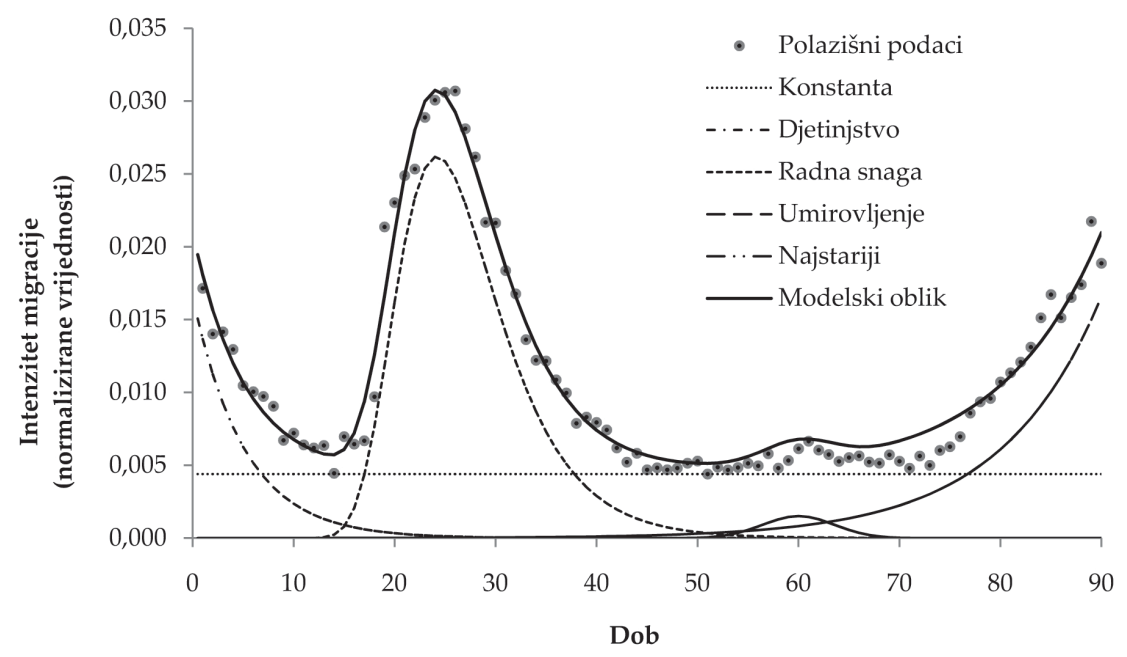

Izvor: izračun autorâ po uzoru na Wilson (2010) 
Rezultati pokazuju da situaciji u Hrvatskoj najbolje odgovara model dobnoga profila unutarnjih migranata u cjelovitoj formi. Vrhunac intenziteta unutarnje migracije prisutan je tijekom druge polovine dvadesetih godina života kod muškaraca, a ponešto ranije kod žena. Slično, sekundarni vrhunac intenziteta unutarnje migracije koji se povezuje s razdobljem oko odlaska u mirovinu očekivano se brže javlja kod žena nego kod muškaraca. Oba procijenjena modela sadržavaju uzlaz intenziteta unutarnje migracije koji se pripisuje najstarijemu dijelu stanovništva.

Postojeći radovi upućuju na određena ograničenja rezultata koje nudi modelski dobni profil unutarnjih migranata (Bernard, Bell i sur., 2014a), što uključuje poteškoće pri određivanju optimalnoga skupa specifičnih krivulja sastavnica (Rees i sur., 2000), nestabilnost procijenjenih parametara (Congdon, 1993) i osjetljivost procjena na polazišne vrijednosti parametara (Rogers, Castro i Lea, 2005). Potrebno je primijeniti pristup pokušaja i pogreške kako bi se odredio skup krivulja i polazišnih parametara koji najbolje opisuje raspoložive podatke (Bernard i Bell, 2015). To izravno utječe na procjene oblika pripadnih krivulja i vrijednosti parametara, zbog čega umanjuje i pouzdanost rezultatâ. Istraživači su predložili pojedine sumarne mjere koje se mogu upotrebljavati u usporednim analizama (Bell i sur., 2002; Bell i Muhidin, 2009; Bernard, Bell i sur., 2014a; Rees i sur., 2000) i za ispitivanje povezanosti dobnoga profila unutarnjih migranata s drugim demografskim procesima tijekom životnoga ciklusa (Bernard, Bell i Charles-Edwards, 2014b). Nadalje, pri procjeni modela izvorne se vrijednosti intenziteta unutarnje migracije normaliziraju (vidi: Wilson, 2010), što dovodi do gubitka informacija o razini geografske mobilnosti. Iz tih se razloga za rigorozniju i komparativno valjanu ocjenu unutarnje pokretljivosti stanovništva u Hrvatskoj iz perspektive životnoga ciklusa razmatra i očekivana migracija, pokazatelj koji će upotpuniti dosadašnje nalaze.

\section{KONCEPT I IZRAČUN OČEKIVANE MIGRACIJE}

Kohortna je analiza veoma važna u demografskim istraživanjima općenito (Glenn, 2005; Hobcraft, Menken i Preston, 1982; Ryder, 1965), pa tako i u ispitivanju migracije (Taeuber, 1966). No, takva je analiza u Hrvatskoj (ali i mnogim drugim zemljama), ponajprije zbog nedostatka prikladnih podataka uglavnom neizvediva. Fertilitet i mortalitet - uz migraciju osnovni demografski procesi - imaju dobro poznate pokazatelje koji su intuitivni i jednostavni za izračun, a zasnivaju se na konceptu sintetičke kohorte i konstruiraju pomoću periodskih podataka. Iako je kao pokazatelj manje za- 
stupljena od totalne stope fertiliteta i očekivanoga trajanja života, očekivana migracija temelji se na analognome konceptu i pruža korisne informacije o unutarnjoj pokretljivosti stanovništva razmatranoga područja.

Očekivana migracija definira se kao broj preseljenja za koje se očekuje da će ih osoba ostvariti tijekom životnoga vijeka (uz uvažavanje djelovanja mortaliteta). Može se poistovjetiti s neto stopom reprodukcije, koja se često upotrebljava u istraživanjima o fertilitetu (Bell, 1996; Rees i sur., 2000). U praksi se izračun očekivane migracije u mnogim slučajevima (Bell, 1996; Bell i sur., 2002; Rees i sur., 2000) provodi na osnovi popisnih podataka koji broje osobe s promijenjenim mjestom stanovanja unutar fiksnoga vremenskog intervala. Pritom se nužno pretpostavlja da su intenzitet unutarnje pokretljivosti i mortalitet konstantni, kao i da do promjene mjesta stanovanja tijekom razmatranoga razdoblja dolazi samo jednom (Rees i sur., 2000). Stoga očekivana migracija ustvari mjeri broj godina s jednim ili više preseljenja, a ne broj samih preseljenja (Long, 1970, 1988: 297).

$\mathrm{U}$ tablici 3 naveden je slijed računskih koraka namijenjenih određivanju očekivane migracije (vidi: Rees i sur., 2000; Rowland, 2003: 401-403; Wilber, 1963). Prvo je potrebno izračunati vjerojatnosti unutarnje migracije (u tablici 3 naveden je postupak koji je prethodno izložen u opisu raspoloživih podataka). Također valja raspolagati pojedinim funkcijama iz tablice doživljenja koja se odnosi na analiziranu zemlju i primjereno razdoblje. Tablica doživljenja za Hrvatsku u 2011. koja se upotrebljava u izračunu u ovome radu preuzeta je s Eurostata (2016).

Varijable i izrazi putem kojih se dolazi do vrijednosti očekivane migracije navedeni su na dnu tablice 3 . Vjerojatnosti unutarnje migracije $m_{x}$ množe se s pripadnim vrijednostima $L_{x}$ funkcije kako bi se dobio očekivani broj tranzicija $L m_{x}$ u hipotetičkoj kohorti. Proizašle se vrijednosti zbrajaju odozdo (analogno postupku generiranja $T_{x}$ funkcije iz tablice doživljenja) s ciljem dolaska do očekivanoga broja selidbi $T m_{x}$ koje će kohorta prema očekivanju ostvariti tijekom ostatka životnoga vijeka. Drugim riječima, $T m_{x}$ pokazuje kumulativni broj preseljenja od svake dobi naviše. Konačno, iznosi očekivane migracije za svaku dob $\mathrm{em}$ dobivaju se dijeljenjem sadržaja $T m_{x}$ stupca s odgovarajućim vrijednostima $l_{x}$ stupca. 
Tablica 3. Potrebne varijable i postupak izračuna očekivane migracije

Table 3. Variables and steps in calculating migration expectancy

\begin{tabular}{lcc}
\hline \multicolumn{1}{c}{ Opis varijable } & Oznaka & Izvor podataka/način izračuna \\
\hline \multicolumn{1}{c}{ Određivanje intenziteta unutarnje migracije } \\
$\begin{array}{l}\text { Migranti prisutni u Hrvatskoj } \\
\text { (doseljeni iz Hrvatske i } \\
\text { inozemstva) }\end{array}$ & (A) & Popis 2011. (DZS) \\
\hline $\begin{array}{l}\text { Stanovništvo prisutno u } \\
\text { Hrvatskoj }\end{array}$ & (B) & Popis 2011. (DZS) \\
\hline $\begin{array}{l}\text { Preživjelo stalno stanovništvo } \\
\text { u Hrvatskoj }\end{array}$ & (C) & $(\mathrm{C})=(\mathrm{B})-(\mathrm{A})$ \\
\hline $\begin{array}{l}\text { Unutarnji migranti u } \\
\text { Hrvatskoj }\end{array}$ & $M_{x}$ & Popis 2011. (DZS) \\
$\begin{array}{l}\text { Preživjelo stalno unutarnje } \\
\text { stanovništvo u Hrvatskoj }\end{array}$ & $P_{x}$ & $P_{x}=(\mathrm{C})+M_{x}$ \\
\hline $\begin{array}{l}\text { Vjerojatnosti unutarnje } \\
\text { migracije u Hrvatskoj } \\
\text { (uvjetovane doživljenjem i } \\
\text { ostankom u zemlji) }\end{array}$ & $m_{x}$ & $\begin{array}{c}m_{x}=\frac{M_{x}}{P_{x}} \\
\text { (Može se pomnožiti sa skalarom } \\
k .)\end{array}$ \\
\hline
\end{tabular}

Potrebne funkcije iz tablice doživljenja

Broj živih određene dobi

u odnosu na početan broj $\quad l_{x} \quad$ Eurostat (2016)

živorođenih

Prosječni broj živih određene dobi

$L_{x} \quad$ Eurostat (2016)

Izračun očekivane migracije

Očekivani broj tranzicija u hipotetičkoj kohorti

$\operatorname{Lm}_{x} \quad L m_{x}=m_{x} \times L_{x}$

Kumulativni broj preseljenja od svake dobi naviše

$\operatorname{Tm} m_{x}$

$$
T m_{x}=\sum_{x}^{x+n} L_{x+n}
$$

(Budući da se podaci u ovome slučaju odnose na jednogodišnje dobne skupine, $n$ iznosi 1.)

Vrijednosti očekivane migracije (broj godina s preseljenjima)

$$
e m_{x} \quad e m_{x}=\frac{T m_{x}}{l_{x}}
$$

Izvor: Rees $i$ sur. (2000), Wilber (1963); prilagođeno za potrebe ovoga rada

Napomena: u čitavoj tablici 3 indeks $x$ označuje jednogodišnje dobne skupine 


\section{REZULTATI I RASPRAVA}

Provedbom procedure navedene $u$ tablici 3 izračunate su vrijednosti očekivane migracije u Hrvatskoj (prema dobi i odvojeno za muškarce i žene). Rezultati su prikazani na slici 5. U slučaju nepromijenjenoga intenziteta unutarnje mobilnosti i konstantnoga mortaliteta iz 2011. muškarci u Hrvatskoj u prosjeku će ostvariti 1,13 preseljenja tijekom životnoga vijeka (vrijednost je očekivane migracije pri rođenju 1,13). Pripadna mjera iznosi 1,47 za žene.

Slika 5. Broj godina s preseljenjima: očekivana migracija u Hrvatskoj

Figure 5. Number of years with moves: migration expectancy in Croatia

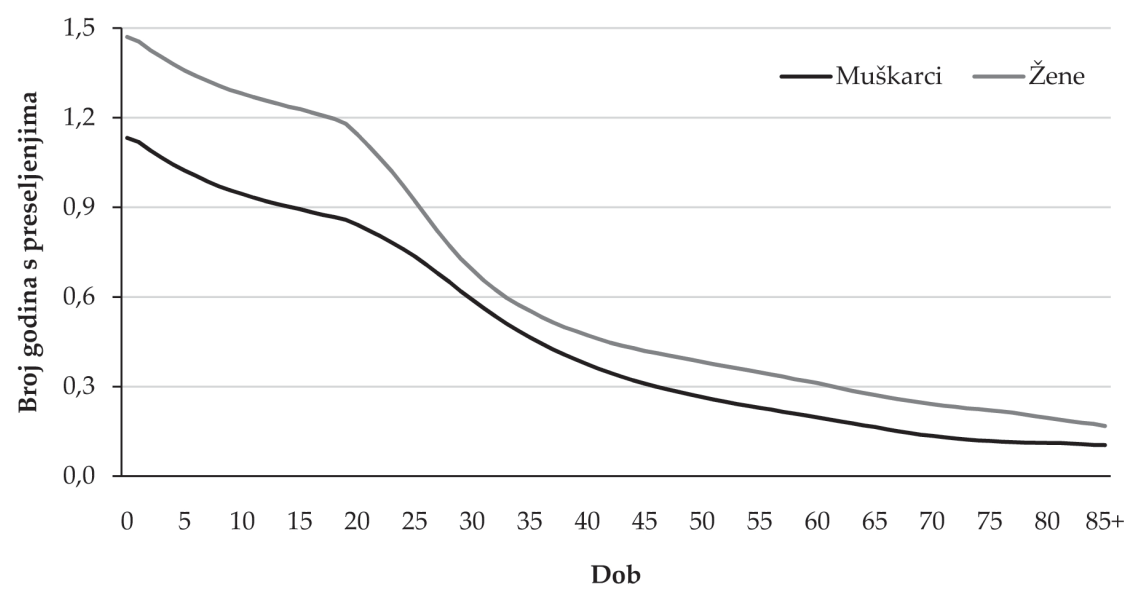

Izvor: izračun autorâ

Veća unutarnja pokretljivost žena samo djelomično proizlazi iz razlika u mortalitetu specifičnih prema spolu (poznato je da žene u prosjeku žive dulje od muškaraca; vidi: Life table). Da su izložene istim učincima mortaliteta kao muškarci, žene bi uz vlastite stope unutarnje mobilnosti u prosjeku promijenile mjesto stanovanja 1,37 puta tijekom životnoga vijeka.

Prije razmatrani dobni profil unutarnjih migranata u Hrvatskoj jasno pokazuje da se sklonost preseljenju mijenja tijekom životnoga ciklusa: prostorna pokretljivost najveća je kod mladoga odraslog stanovništva. No, kako ističe Bell (1996: 104), očekivana migracija uz primjenu alata tablice doživljenja omogućuje koncizniju analizu vremenskoga rasporeda unutarnje mobilnosti tijekom životnoga vijeka. Dob pri kojoj će se ostvariti polovina broja 
preseljenja može se odrediti nalaženjem točke gdje je $T m_{0}$ vrijednost dvostruko umanjena. To je za muškarce 30,47 , a za žene 28,69 godina života. Slično, lako je ustanoviti da će muškarci ostvariti četvrtinu broja preseljenja s 19,07, a tri četvrtine s 46,32 godine života. Analogne su vrijednosti za žene redom 20,87 i 50,43 godine života.

Proporcija cjeloživotne unutarnje mobilnosti pri bilo kojoj dobi $y$ unutar intervala $x, x+n$ definirana je formulom (Bell, 1996: 104)

$$
\frac{T m_{x}-T m_{x+n}}{T m_{y}}
$$

gdje je $x>y$. Pomoću izraza (3) na jednostavan se način može odrediti proporcija cjeloživotne unutarnje mobilnosti koja će se ostvariti tijekom radnoga vijeka pojedinca. Pretpostavi li se da muškarci sudjeluju na tržištu rada od 18. do 65. godine života, izraz (3) poprima oblik

$$
\frac{T m_{18}-T m_{65}}{T m_{0}}
$$

iz čega proizlazi da se $64,72 \%$ cjeloživotne unutarnje mobilnosti odvija unutar definiranoga dobnog raspona. Za žene (uz pretpostavku izlaska s tržišta rada sa 60 godina života) odgovarajući udio iznosi $61,07 \% .{ }^{11}$ Na osnovi istoga principa određuje se i proporcija prostorne pokretljivosti koja se odnosi na mlado odraslo stanovništvo: kod muškaraca će se unutar dobnoga raspona od 18 do 35 godina odviti 35,88\% cjeloživotne unutarnje mobilnosti, a kod žena (unutar jednakoga dobnog raspona) čak 43,62\%.

Opisana tehnika omogućuje i izračun proporcije cjeloživotne unutarnje mobilnosti koja je uvjetovana doživljenjem do neke proizvoljno zadane dobi. Iz inačice izraza (3)

$$
\frac{T m_{18}-T m_{35}}{T m_{18}}
$$

proizlazi da će, uz uvjet da dožive 18 godina, muškarci do navršenih 35 godina ostvariti $47,24 \%$ preostale cjeloživotne mobilnosti, a žene $53,96 \%$.

11 Od 2014. žene pravo na starosnu mirovinu ostvaruju sa 61 godinom, a navedena će se dob do 2030. povećavati za tri mjeseca godišnje; detaljnije vidjeti na internetskim stranicama Hrvatskoga zavoda za mirovinsko osiguranje (http://www.mirovinsko.hr). Uz pretpostavku izlaska s tržišta rada sa 61 godinom udio cjeloživotne unutarnje mobilnosti za žene iznosi $61,73 \%$, a isti je udio unutar dobnoga raspona od 18 do 65 godina $64,21 \%$. 
Dodatnih 18,22\% kod muškaraca i 11,20\% kod žena odvit će se (uz isti uvjet) unutar dobnoga raspona od 40 do 55 godina.

Vrijednosti očekivane migracije postupno se umanjuju s dobi. Takav se obrazac bilježi i kod očekivanoga trajanja života, ali je vidljivo ujednačeniji. Na slici 6 distribucija unutarnje mobilnosti uspoređuje se s udjelom ukupnoga životnog vijeka provedenoga unutar određenoga dobnog raspona. Još je jednom jasno predočena uvećana sklonost promjeni mjesta stanovanja kod mladoga odraslog stanovništva.

Slika 6. Distribucija preseljenja i godina života prema spolu

Figure 6. Distribution of moves and years lived by sex

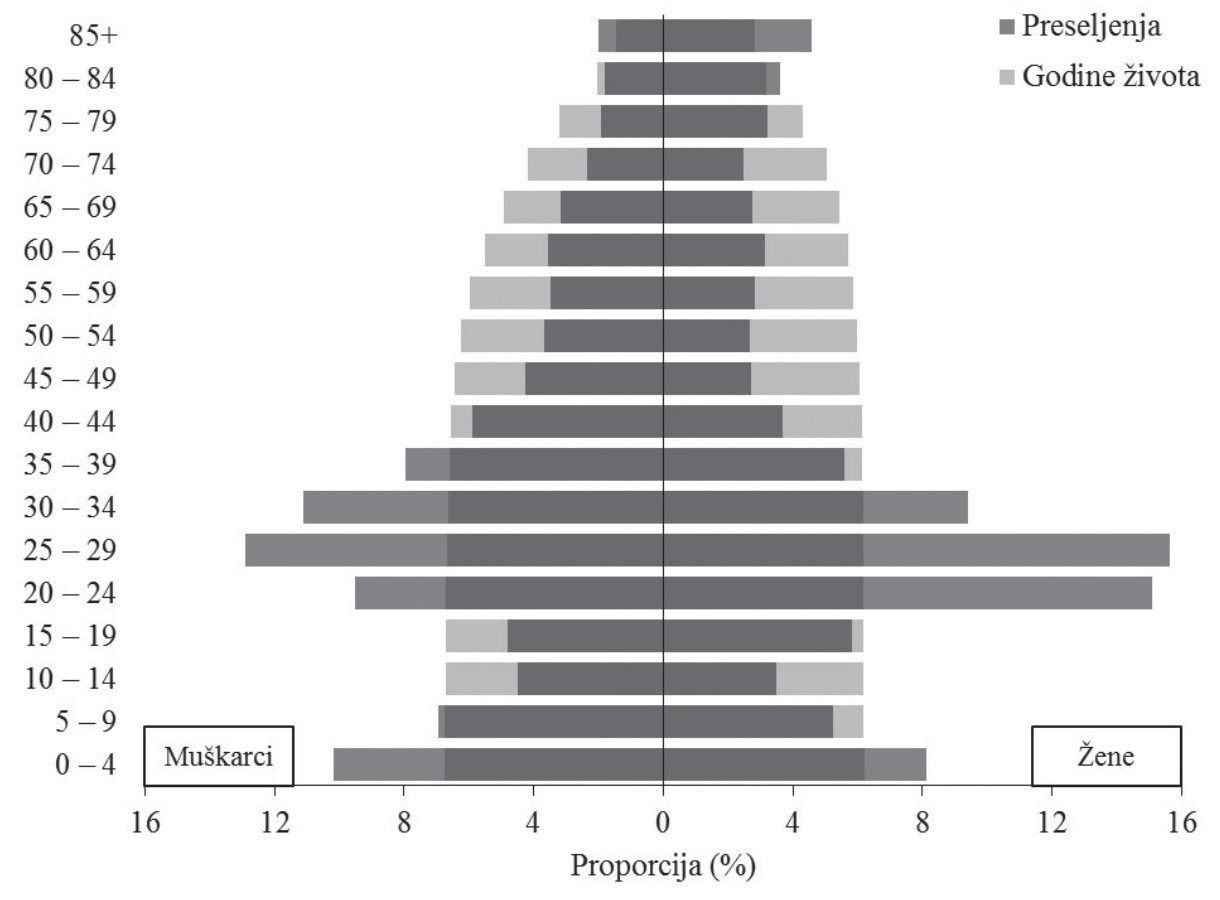

Izvor: izračun autorâ

Distribucija godina života uobičajenoga je oblika i pada kod najstarijega dijela stanovništva, što predstavlja odraz djelovanja mortaliteta. S druge strane, preseljenja su najčešća u dobnome rasponu od 20 do 34 godine. Najveća proporcija prostorne pokretljivosti kod oba spola pripisuje se stanovništvu u drugoj polovini dvadesetih godina života. Kod muškaraca će se unutar dobnoga raspona od 20 do 34 godine odviti 33,53\% cjeloživotne 
unutarnje mobilnosti, no taj dobni raspon predstavlja tek 19,99\% ukupnoga životnog vijeka. Kod žena je situacija slična, pa i izraženija: unutar istoga dobnog raspona, koji zauzima 18,51\% životnoga vijeka, odvit će se 40,08\% cjeloživotne unutarnje mobilnosti. U kasnijim dobnim skupinama dolazi do obrata - muškarcima s 50 godina života preostaje još 33,52\% životnoga vijeka i 21,95\% cjeloživotne unutarnje mobilnosti, a ženama s 50 godina života još $38,40 \%$ životnoga vijeka i $25,25 \%$ cjeloživotne unutarnje mobilnosti.

Postoje i dodatne mjere koje se mogu izvesti na osnovi očekivane migracije (Rees i sur., 2000: 218). Dijeljenjem očekivane migracije s očekivanim trajanjem života dolazi se do stope unutarnje mobilnosti koja je standardizirana prema dobi. Oprečno, dijeljenjem očekivanoga trajanja života s očekivanom migracijom dolazi se do prosječne duljine stanovanja na jednome mjestu. Te su mjere izračunate za muškarce i žene u Hrvatskoj i navedene u tablici 4.

Tablica 4. Pokazatelji koji se temelje na očekivanoj migraciji Table 4. Indicators based upon migration expectancy

\begin{tabular}{|c|c|c|}
\hline Spol & Izračun pokazatelja & Ishodišna vrijednost \\
\hline \multicolumn{3}{|c|}{ Stopa unutarnje mobilnosti standardizirana prema dobi } \\
\hline Muškarci & $e m_{0}$ & 0,015 \\
\hline Žene & $e_{0}$ & 0,018 \\
\hline \multicolumn{3}{|c|}{ Prosječna duljina stanovanja na jednome mjestu } \\
\hline Muškarci & $e_{0}$ & 65,16 \\
\hline Žene & $e m_{0}$ & 54,67 \\
\hline \multicolumn{3}{|c|}{$\begin{array}{l}\text { Upotrijebljene oznake: } \\
\text { em }=\text { očekivana migracija pri rođenju } \\
e_{0}=\text { očekivano trajanje života pri rođenju }\end{array}$} \\
\hline
\end{tabular}

Izvor: izračun autorâ

Izloženi rezultati pokazuju da dobni profil prostorne pokretljivosti stanovništva u Hrvatskoj odgovara očekivanjima postojeće literature. No, također je uočljivo da je unutarnja mobilnost stanovništva u Hrvatskoj komparativno jako niska. Međunarodne varijacije $\mathrm{u}$ intenzitetu unutarnje migracije privlače pozamašnu istraživačku pozornost, a dostupna objaš- 
njenja pozivaju se na takozvanu kulturu mobilnosti (Long, 1991), tranziciju prostorne pokretljivosti (Zelinsky, 1971), događaje tijekom životnoga ciklusa i rješavanje stambenoga pitanja (Bernard, Bell i sur., 2014b; Raymer i Rogers, 2008; Rogers i Castro, 1981) te geografske, ekonomske, društvene i demografske indikatore razvoja zemalja (Bell, Charles-Edwards, Ueffing i sur., 2015). Ta objašnjenja mogu poslužiti kao kvalitetno polazište za buduća istraživanja o uzročnicima niske unutarnje mobilnosti stanovništva u Hrvatskoj.

\section{ZAKLJUČAK}

U ovome radu istraživanju unutarnje migracije stanovništva u Hrvatskoj pristupilo se iz perspektive životnoga ciklusa. Najprije je ispitan dobni profil unutarnjih migranata. Pokazalo se da polazišnim podacima najbolje odgovara cjeloviti modelski oblik, a proizašle procjene očekivano su potvrdile da je vrhunac intenziteta prostorne pokretljivosti prisutan tijekom dvadesetih godina života (kod žena ponešto ranije u odnosu na muškarce).

U nekim se radovima (Bell, 1996; Bell i sur., 2002; Long, 1970, 1973, 1988) očekivana migracija upotrebljava za praćenje promjena u prostornoj pokretljivosti stanovništva tijekom kalendarskoga vremena, no takva je analiza u slučaju Hrvatske otežana zbog metodoloških razlika u načinu prikupljanja popisnih podataka. Osim toga, pojedini autori (Bell, 1996; Long, 1973) oslanjaju se na očekivanu migraciju kako bi ispitali u kojoj se mjeri unutarnja mobilnost razlikuje među određenim skupinama stanovništva. No, definiraju li se te skupine na osnovi promjenjivih obilježja stanovništva (poput bračnoga stanja, razine obrazovanja i ekonomske aktivnosti), dobivene rezultate treba oprezno interpretirati jer metode tablice doživljenja ujedinjuju presječna iskustva međusobno nezavisnih kohorti. Nažalost, izračun očekivane migracije za različite skupine stanovništva u ovome je radu ograničen raspoloživim podacima na razradu prema spolu. Zbog nedovoljno detaljnih podataka onemogućena je i raščlamba očekivane migracije s obzirom na vrstu preseljenja.

Izračun očekivane migracije poslužio je kao podloga za podrobnije ispitivanje koncentracije prostorne pokretljivosti stanovništva u Hrvatskoj u različitim fazama životnoga ciklusa. Očekivana migracija s dobi pada, no distribucija preseljenja neujednačena je tijekom životnoga vijeka. Žene su u usporedbi s muškarcima u prosjeku sklonije promjeni mjesta stanovanja, a taj zaključak vrijedi i nakon uvažavanja spolnih razlika u mortalitetu. Dobivene vrijednosti očekivane migracije upućuju na komparativno jako nisku 
unutarnju mobilnost stanovništva u Hrvatskoj, što je, između ostaloga, moguća posljedica načina rješavanja stambenoga pitanja, ekonomskih i društvenih prilika. Osim toga, u radu je pokazano da je sklonost preseljenju ovisna o dobi, odnosno da su stariji ljudi manje skloni selidbama. Uzimajući u obzir nastavak starenja hrvatskoga stanovništva, uz nepromijenjene ostale čimbenike, može se očekivati još manja unutarnja mobilnost u budućnosti, što može ostaviti značajne posljedice na pojedine gospodarske djelatnosti.

Očekivana migracija razumljiv je pokazatelj koji se lako može povezati s pojedinačnim iskustvom. Nije pod utjecajem dobne strukture stanovništva i nudi niz komplementarnih mjera namijenjenih razumijevanju cjeloživotne unutarnje mobilnosti unatoč nedostatku kohortnih podataka. No, budući da se temelji na popisnim podacima koji mjere tranzicije (a ne događaje) unutar fiksno određenoga vremenskog intervala, važno je imati na umu da očekivana migracija nudi tek ograničenu sliku unutarnje mobilnosti stanovništva. Riječ je, naime, o pokazatelju koji se odnosi na prosječne vrijednosti, zbog čega može prikrivati važne informacije o varijacijama u migracijskome ponašanju. Detaljnija analiza iziskuje potpunije podatke o broju i vrsti preseljenja i obilježjima osoba koje mijenjaju mjesto stanovanja. Takvi podaci mogu se dobiti iz detaljnih anketnih istraživanja o prostornoj pokretljivosti ili kontinuiranoga registra stanovništva jer ti izvori prikupljaju informacije o svim promjenama uobičajenoga mjesta boravka. Dakle, evidentna je potreba za unapređenjem kvalitete i obuhvata migracijske statistike u Hrvatskoj.

\section{LITERATURA}

Bailey, M. i Sly, D. F. (1987). Metropolitan-nonmetropolitan migration expectancy in the United States, 1965 - 1980, Genus, 43 (3-4): 37-60.

Bates, J. i Bracken, I. (1982). Estimation of Migration Profiles in England and Wales, Environment and Planning A, 14 (7): 889-900, doi: 10.1068/a140889.

Bell, M. (1996). How often do Australians move? Alternative measures of population mobility, Journal of the Australian Population Association, 13 (2): 101-124, doi: 10.1007/ bf03029490.

Bell, M., Blake, M., Boyle, P., Duke-Williams, O., Rees, P., Stillwell, J. i Hugo, G. (2002). Cross-national comparison of internal migration: Issues and measures, Journal of the Royal Statistical Society: Series A (Statistics in Society), 165 (3): 435-464, doi: 10.1111/1467-985x.t01-1-00247.

Bell, M. i Charles-Edwards, E. (2013). Cross-national comparisons of internal migration: An update on global patterns and trends. New York: United Nations Department of Economic and Social Affairs: Population Division (Technical Paper, 2013/1). 
Bell, M., Charles-Edwards, E., Kupiszewska, D., Kupiszewski, M., Stillwell, J. i Zhu, Y. (2015). Internal Migration Data Around the World: Assessing Contemporary Practice, Population, Space and Place, 21 (1): 1-17, doi: 10.1002/psp.1848.

Bell, M., Charles-Edwards, E., Ueffing, P., Stillwell, J., Kupiszewski, M. i Kupiszewska, D. (2015). Internal Migration and Development: Comparing Migration Intensities Around the World, Population and Development Review, 41 (1): 33-58, doi: 10.1111/j.1728-4457.2015.00025.x.

Bell, M. i Muhidin, S. (2009). Cross-National Comparisons of Internal Migration. New York: United Nations Development Programme (Human Development Research Paper, 2009/30).

Bernard, A. i Bell, M. (2015). Smoothing internal migration age profiles for comparative research, Demographic Research, 32 (33): 915-948, doi: 10.4054/DemRes.2015.32.33.

Bernard, A., Bell, M. i Charles-Edwards, E. (2014a). Improved measures for the crossnational comparison of age profiles of internal migration, Population Studies, 68 (2): 179-195, doi: 10.1080/00324728.2014.890243.

Bernard, A., Bell, M. i Charles-Edwards, E. (2014b). Life-Course Transitions and the Age Profile of Internal Migration, Population and Development Review, 40 (2): 231-239, doi: 10.1111/j.1728-4457.2014.00671.x.

Bernard, A., Ueffing, P., Bell, M. i Charles-Edwards, E. (2014). The IMAGE Repository Userguide. Queensland: Queensland Centre for Population Research (QCPR Working Paper, 2014/01), https://www.gpem.uq.edu.au/docs/qcpr/ ImageReposirtyUserGuide.pdf (10. 03. 2016.).

Congdon, P. (1993). Statistical Graduation in Local Demographic Analysis and Projection, Journal of the Royal Statistical Society: Series A (Statistics in Society), 156 (2): 237-270, doi: 10.2307/2982731.

Courgeau, D. (1979). Migrants and migrations, Population: Selected Papers, 3: 1-35.

Courgeau, D., Muhidin, S. i Bell, M. (2012). Estimating Changes of Residence for CrossNational Comparison, Population, 67 (4): 631-651, doi: 10.3917/pope.1204.0631.

Gelo, J., Akrap, A. i Čipin, I. (2005). Temeljne značajke demografskog razvoja Hrvatske: (bilanca 20. stoljeća). Zagreb: Ministarstvo obitelji, branitelja i međugeneracijske solidarnosti.

Glenn, N. D. (2005). Cohort Analysis. Thousand Oaks: Sage.

Hobcraft, J., Menken, J. i Preston, S. (1982). Age, Period, and Cohort Effects in Demography: A Review, Population Index, 48 (1): 4-43, doi: 10.2307/2736356.

Jaffe, A. J. (1960). Handbook of Statistical Methods for Demographers. Washington, DC: US Government Printing Office.

Kitsul, P. i Philipov, D. (1980). The One-Year - Five-Year Migration Problem. Laxenburg: International Institute for Applied Systems Analysis (IIASA Working Paper WP-80081).

Klempić Bogadi, S., Gregurović, M., Blažević, J. i Kudra Beroš, V. (2015) Bibliografija radova objavljenih u časopisu Migracijske teme / Migracijske i etničke teme (1985. 2014.), Migracijske i etničke teme, 31 (1): 115-175, doi: 10.11567/met.31.1.4.

Klempić Bogadi, S. i Lajić, I. (2014). Suvremena migracijska obilježja statističkih jedinica Republike Hrvatske, Migracijske i etničke teme, 30 (3): 437-377, doi: 10.11567/met.30.3.7.

Kulkarani, M. i Pol, L. G. (1994). Migration expectancy revisited: Results for the 1970s, 1980s and 1990s, Population Research and Policy Review, 13 (2): 195-202, doi: 10.1007/ bf01080203. 
Lajić, I. (2002). Hrvatske migracije početkom 21. stoljeća, Migracijske i etničke teme, 18 (2-3): 135-149.

Long, J. F. i Boertlein, C. G. (1990). Comparing Migration Measures Having Different Intervals. Washington DC: US Department of Commerce, Bureau of Census (Current Population Reports, Series P-23, 166).

Long, L. H. (1970). On Measuring Geographic Mobility, Journal of the American Statistical Association, 65 (331): 1195-1203, doi: 10.1080/01621459.1970.10481154.

Long, L.H.(1973). New Estimates of Migration Expectancy in the United States, Journal of the American Statistical Association, 68 (341): 37-43, doi: 10.1080/01621459.1973.10481330.

Long, L. H. i Boertlein, C. G. (1976). The Geographical Mobility of Americans: An International Comparison. Washington DC: US Department of Commerce, Bureau of Census (Current Population Reports, Special Studies Series P-23, 64).

Long, L. H. (1988). Migration and Residential Mobility in the United States. New York: Russel Sage Foundation.

Long, L. (1991). Residential Mobility Differences among Developed Countries, International Regional Science Review, 14(2):133-147, doi:10.1177/016001769101400202.

Mikačić, V. (2000). Prostorna pokretljivost stanovništva Hrvatske - unutarnja migracija, Hrvatski geografski glasnik, 62 (1): 1-21.

Nejašmić, I. (1992). Osnovne značajke unutarnje migracije stanovništva Hrvatske 1880. 1981., Migracijske i etničke teme, 8 (2): 141-166.

Nejašmić, I. (2015). Iseljavanje iz Hrvatske od 1900. do 2001.: demografske posljedice stoljetnog procesa, Migracijske i etničke teme, 30 (3): 405-435, doi: 10.11567/met.30.3.6.

Plane, D. A. i Heins, F. (2003). Age articulation of US inter-metropolitan migration flows, The Annals of Regional Science, 37 (1): 107-130, doi: 10.1007/s001680200114.

Pokos, N. (1999). Procjena broja iseljenih stanovnika Republike Hrvatske od Popisa stanovništva 1991. do 30. lipnja 1998. godine, Društvena istraživanja, 8 (5-6): 725-734.

Raymer, J. i Rogers, A. (2008). Applying model migration schedules to represent agespecific migration flows, u: J. Raymer i F. Willekens (ur.). International Migration in Europe: Data, Models and Estimates. Chichester: Wiley, 175-192.

Rees, P., Bell, M., Duke-Williams, O. i Blake, M. (2000). Problems and solutions in the measurement of migration intensities: Australia and Britain compared, Population Studies, 54 (2): 207-222, doi: 10.1080/713779082.

Rogers, A. (1988). Age patterns of elderly migration: An international comparison, Demography, 25 (3): 355-370, doi: 10.2307/2061537.

Rogers, A. i Castro, L. J. (1981). Model Migration Schedules. Laxenburg: International Institute for Applied Systems Analysis (Research Report RR-81-30).

Rogers, A. i Castro, L. J. (1986). Migration, u: A. Rogers i F. Willekens (ur.). Migration and Settlement: A Multiregional Comparative Study. Dordrecht: D. Reidel, 157-208.

Rogers, A., Castro, L. J. i Lea, M. (2005). Model Migration Schedules: Three Alternative Linear Parameter Estimation Methods, Mathematical Population Studies: An International Journal of Mathematical Demography , 12 (1): 17-38, doi: 10.1080/08898480590902145.

Rogers, A., Little, J. i Raymer, J. (2010). The Indirect Estimation of Migration: Methods for Dealing with Irregular, Inadequate, and Missing Data. Dordrecht: Springer.

Rogers, A., Racquillet, R. i Castro, L. J. (1978). Model Migration Schedules and Their Applications, Environment and Planning A, 10 (5): 475-502, doi: 10.1068/a100475. 
Rogers, A. i Rajbhandary, S. (1997). Period and cohort age patterns of US migration 1948 - 1993: Are American males migrating less?, Population Research and Policy Review, 16 (6): 513-530, doi: 10.1023/A:1005824219973.

Rogers, A. i Watkins, J. (1987). General Versus Elderly Interstate Migration and Population Redistribution in the United States, Research on Aging, 9 (4): 483-529, doi: 10.1177/0164027587094002.

Rogerson, P. A. (1990). Migration analysis using data with time intervals of differing widths, Papers of the Regional Science Associations, 68 (1): 97-106, doi: 10.1007/ bf01933910.

Rowland, D. T. (2003). Demographic Methods and Concepts. New York: Oxford University Press.

Ryder, N. B. (1965). The Cohort as a Concept in the Study of Social Change, American Sociological Review, 30 (6): 834-861, doi: 10.2307/2090964.

Stillwell, J., Daras, K., Bell, M. i Lomax, N. (2014). The IMAGE studio: A Tool for Internal Migration Analysis and Modelling, Applied Spatial Analysis and Policy, 7 (1): 5-23, doi: 10.1007/s12061-014-9104-4.

Taeuber, K. E. (1966). Cohort migration, Demography, 3 (2): 416-422, doi: 10.2307/2060167.

US Census Bureau (2016). Migration/Geographic Mobility: Calculating Migration Expectancy Using ASC Data, https://www.census.gov/hhes/migration/about/cal-mig-exp.html (17. 02. 2016.).

Wilber, G. L. (1963). Migration Expectancy in the United States, Journal of the American Statistical Association, 58 (302): 444-453, doi: 10.1080/01621459.1963.10500857.

Wilson, T. (2010). Model migration schedules incorporating student migration peaks, Demographic Research, 23 (8): 191-222, doi: 10.4054/DemRes.2010.23.8.

Zelinsky, W. (1971). The Hypothesis of the Mobility Transition, Geographical Review, 61 (2): 219-249, doi: 10.2307/213996.

\section{IZVORI}

Popis stanovništva, kućanstava i stanova 2011. godine, Državni zavod za statistiku, Zagreb, http://www.dzs.hr/

Migracija stanovništva Republike Hrvatske, Državni zavod za statistiku, Zagreb, http:// www.dzs.hr/

Life table, Eurostat, http://ec.europa.eu/eurostat/data/database (16. 02. 2016.).

Hrvatski zavod za mirovinsko osiguranje, http://www.mirovinsko.hr (12. 04. 2016.). 


\title{
Population Mobility in Croatia from a Life Course Perspective
}

\author{
Ivan Čipin, Marin Strmota, Petra Međimurec
}

\begin{abstract}
SUMMARY
Spatial mobility receives a lot of research attention in Croatia. Many studies deal with international migration (Nejašmić, 2015; Lajić, 2002; Pokos, 1999; Gelo, Akrap and Čipin, 2005) as it is becoming an increasingly important component of population change. Movement of people within country also seeks thorough investigation internal migration can have a considerable impact on the changing size and composition of population residing in local areas. However, existing literature on internal migration in Croatia (Klempić Bogadi and Lajić, 2014; Mikačić, 2000; Nejašmić, 1992) provides little information on lifetime population mobility.
\end{abstract}

This paper employs a life course perspective to explore internal population mobility in Croatia. In the absence of cohort data on internal migration, the application of life table methods offers a way of estimating lifetime population mobility. The outcome is migration expectancy - the average number of moves an individual may expect to make during his or her lifetime (making allowance for the effect of mortality). Migration expectancy was first introduced by Wilber (1963) and further developed by Long $(1970,1973,1988)$. The same concept has been successfully applied to assess internal population mobility in several countries (e.g. Long and Boertlein, 1976; Kulkarani and Pol, 1994; Bell, 1996; Rees et al., 2000; US Census Bureau, 2016).

Migration expectancy offers a number of advantages compared to conventional measures of internal population mobility (Bell, 1996: 108-109; Bell et al., 2002: 446). Firstly, it is both readily understood and statistically valid. Computation of migration expectancy is transparent and straightforward - it requires the use of simple spreadsheet procedures. Secondly, migration expectancy enables a detailed examination of internal mobility timing. Thirdly, life table stationary population used to determine migration expectancy automatically standardizes for varying age structures, thus allowing for direct comparisons of internal mobility between different populations and time periods.

The data used to calculate migration expectancy in this paper are census-based and refer to people who moved to or within Croatia between April $1^{\text {st }} 2010$ and March $31^{\text {st }}$ 2011. These are known as transition-type data (Courgeau, 1979; Rees et al., 2000) which count surviving (in-)migrants rather than migration events. Internal migration intensities by sex and single years of age were obtained in accordance with existing recommendations for handling this sort of data (Rees et al., 2000). Resulting figures therefore pertain to migration probabilities conditional upon survival within the country.

Key assumptions concerning migration expectancy are constant levels of mortality and internal population mobility, and movers changing residence only once during the observation period. Since migration expectancy calculation disregards the possibility of multiple moves within a given time interval, the outcome technically shows the number of years with one or more residential changes, rather than the number of 
residential changes in itself (Long, 1970, 1988: 297). However, the latter, looser definition of migration expectancy is commonly used for ease of interpretation.

Before turning to analysis of migration expectancy, this paper considers variation of migration intensities by age. Internal migration age patterns are known to show persistent regularities (Rogers, Racquillet and Castro, 1978; Rogers and Castro, 1981, 1986; Rogers and Watkins, 1987; Raymer and Rogers, 2008). A formal representation of such regularities is provided by model migration schedules. Researchers identified four broad families of model migration schedules (Rogers and Castro, 1981, 1986; Rogers and Watkins, 1987; also see: Raymer and Rogers, 2008; Rogers, Little and Raymer, 2010; for a later extension see: Wilson, 2010). The standard age profile of internal migration exhibits a heightened propensity to move during young adulthood when people oftentimes change residence for employment or partnership opportunities. After reaching a peak at labor force ages, migration proneness gradually declines due to mobility depressing influences (e.g. finding a stable job or having school-aged children). Other age profiles of internal migration account for a secondary peak at retirement ages when people may relocate to find most suitable housing, or a post-retirement migration intensity upslope which captures moves by individuals of the oldest ages to institutional settings. The full age profile of internal migration includes both extensions of the standard schedule. This model specification was found to yield the best description of observed age-specific migration intensities in Croatia. Parameter estimates expectedly reveal that migration intensity peaks during mid- to late twenties (somewhat sooner for females compared to males). Migration intensity reaches a low point in late middle ages. A secondary peak, although quite small, is visible throughout the early sixties (again, somewhat sooner for females compared to males). The schedule also identifies the presence of a conspicuous upward slope for the elderly.

Model schedules assume a typical shape of internal migration age patterns based upon a theoretically sound link between mobility behavior and life course transitions. However, the estimation of model schedules has been related to certain limitations (e.g. Bernard, Bell and Charles-Edwards, 2014a), including the variability in the number and value of parameter estimates, the sensitivity of parameter estimates to initial value selection, and issues concerning instability, comparability and interpretability of parameter estimates. Furthermore, the age schedule is normalized to unity prior to parameter estimation, which leads to a loss of information on the level of migration activity. Finally, knowing the age-specific migration profile is insufficient to draw precise conclusions about the timing of mobility. The application of life table techniques combined with migration expectancy values by single years of age provides the facility to thoroughly explore the way mobility is concentrated over the life course.

Assuming unchanged levels of mortality and internal mobility, an average male in Croatia is expected to make 1.13 moves in his lifetime (in other words, migration expectancy at birth amounts to 1.13 for males). The corresponding figure for an average female is 1.47 moves. Higher female residential mobility is only partially attributable to sex-specific mortality differentials. If females were exposed to the same mortality regime as males, but kept their own internal migration intensities, they would be expected to make 1.37 moves in their lifetime. The age at which half of all internal mobility is completed is estimated to be 30.47 for males and 28.69 for females. Almost two thirds (64.72\%) of male lifetime mobility occur during the usual labor force years (between ages 18 and 65). The proportion of total lifetime moves made by fe- 
males between ages 18 and 60 is assessed at $61.07 \%$. Highly mobile young adulthood (ages 18 to 35 ) accounts for $35.88 \%$ of lifetime moves for males and $43.62 \%$ of lifetime moves for females. The figures become even larger if conditioned upon survival to age 18, taking the values of $47.24 \%$ and $53.96 \%$ respectively. Much like life expectancy, migration expectancy declines progressively with age, but the distribution of internal mobility over the life course obviously follows an uneven shape. Ages 20 to 34 take up $19.99 \%$ of the average male lifespan, but this age range occupies $33.53 \%$ of lifetime moves. The comparable figures for females are even more pronounced: the same age interval, which pertains to $18.51 \%$ of the average female lifespan, accounts for $40.08 \%$ of total lifetime mobility.

Other authors (e.g. Bell, 1996; Long, 1973) have also used migration expectancy to compare internal mobility between different population subgroups. However, if such subgroups are determined on the basis of changing population characteristics (e.g. marital or employment status), the findings should be interpreted with caution because life table methods unify cross-sectional experiences of mutually independent cohorts. Unfortunately, analyses of this kind were infeasible in the current study due to data limitations. Insufficiently detailed data also constrained the obtaining of migration expectancy figures by type of move. Additionally, temporal comparisons of migration expectancy in Croatia are made difficult by methodological inconsistencies between census data collections. After making appropriate adjustments to derive the population at risk, have been found no substantial change of migration expectancy in Croatia over the last decade.

The results of this study reveal that internal population mobility in Croatia is comparatively very low. This may be attributable to housing adjustment behavior, social and economic conditions. However, unraveling the causes of cross-national differences in internal migration intensities is beyond the scope of this paper. Existing literature (e.g. Bell, Charles-Edwards, Ueffing et al., 2015; Bernard, Bell and CharlesEdwards, 2014b; Long, 1991; Zelinsky, 1971) provides a sound foundation for future research on determinants of low residential mobility in Croatia.

One should bear in mind that migration expectancy is based on cross-sectional data and shows the experience of a synthetic cohort. Its values therefore represent merely averages which may conceal substantial variations in mobility conduct. Nonetheless, migration expectancy is an intuitive and practical indicator which enables a thorough examination of internal mobility timing. As such, it contributes to existing knowledge on internal population mobility in Croatia.

KEY WORDS: migration, internal population mobility, life course perspective, Croatia 